\title{
Hubungan antara Pengetahuan dan Sosial Ekonomi dengan Penyakit Gout Arthritis pada Lansia di Wilayah Kerja Puskesmas Lawanga
}

\section{The relationship between knowledge and socio-economics with gout arthritis in the elderly in the working area of Lawanga Health Center}

\author{
Ni Made Dewi Susanti ${ }^{1,}$ Asrina A. Sumaga ${ }^{2}$ \\ ${ }^{1}$ Sekolah Tinggi Ilmu Kesehatan Husada Mandiri Poso \\ ${ }^{2}$ Program Studi Sarjana Keperawatan Stikes Husada Mandiri Poso \\ Email: nimadedewi09@gmail.com; Asrinasumaga@ gmail.com
}

\begin{abstract}
Background: Gout Arthritis is one of the rheumatic diseases that ranks third after arthrosis and rheumatoid arthritis. People with rheumatic disease in Indonesia are estimated to have nearly $80 \%$ of the population aged 40 years or more. Factors that can affect gout arthritis are lack of public knowledge about joint pain because of not all complaints of joint pain caused by gout. Objective: This study was to find out factors related to gout arthritisin the elderly in the Lawanga Health Center Working Area. Research Method is an analytical study with a cross-sectional approach. The population in this study were elderly respondents who suffered from the gout arthritis. The sample is 46 respondents. Data analysis was done by univariate and bivariate using Chi-Square test with an alpha significance value of 5\% (=0.05). Results: This study showed an association between knowledge with gout arthritis $(p=0.036)$; there was an association between socio-economic and gout arthritis $(\mathrm{p}=0.047)$. Conclusion: education and socio-economics are associated with gout arthritis.
\end{abstract}

Keywords: Education, Social economy, Gout arthritis

\begin{abstract}
Abstrak
Latar Belakang : Gout Arthritis adalah salah satu penyakit rematik yang menduduki urutan ketiga setelah arthrosis dan remathoid arthritis. Penderita penyakit rematik di Indonesia di perkirakan hampir $80 \%$ penduduk yang berusia 40 tahun atau lebih. Faktor yang dapat mempengaruhi penyakit gout arthritis yaitu kurangnya pengetahuan masyarakat mengenai nyeri pada sendi karena tidak semua keluhan dari nyeri sendi disebabkan oleh asam urat. Tujuan: penelitian ini adalah untuk mengetahui faktor yang berhubungan dengan penyakit gout arthritis pada lansia di Wilayah Kerja Puskesmas Lawanga.

Metode Penelitian : merupakan penelitian anaitik dengan pendekatan secara cross sectional. Populasi dalam penelitian ini adalah responden lansia yang menderita gout arthritis. Sampel berjumlah 46 orang responden. Analisis data dilakukan secara univariat dan bivariat menggunakan uji Chi Square dengan nilai signifikansi alpha 5\% ( =0,05).

Hasil : penelitian ini menunjukan adanya hubungan antara pengetahuan dengan penyakit gout arthritis $(p=0,036)$, terdapat adanya hubungan antara sosial ekonomi dengan penyakit gout
\end{abstract}


arthritis $(p=0,047)$. Kesimpulan: pengetahuan dan sosial ekonomi berhubungan dengan penyakit gout arthritis.

Kata Kunci : Pengetahuan, Sosial ekonomi, Gout arthritis

\section{PENDAHULUAN}

Gout Arthritis adalah salah satu penyakit rematik yang menduduki urutan ketiga setelah arthrosis dan remathoid arthritis, penderita penyakit rematik di Indonesia di perkirakan hampir $80 \%$ penduduk yang berusia 40 tahun atau lebih (1). World Health Organization (WHO) memperkirakan bahwa sekitar 335 juta orang di dunia mengidap penyakit asam urat. Jumlah ini sesuai dengan adanya peningkatan manusia berusia lanjut. Masalah muskuloskeletal merupakan masalah kronis yang paling lazim terjadi pada lansia, dengan sekitar 49\% lansia mengalami beberapa bentuk artritis (2).

Di Indonesia, penyakit artritis gout pertama kali diteliti oleh seorang dokter Belanda, van den Horst, pada 1935. Saat itu, ia menemukan 15 kasus gout berat pada masyarakat kurang mampu di Jawa. Hasil penelitian tahun 1988 oleh John Darmawan di Bandungan, Jawa Tengah menunjukkan bahwa diantara 4.683 orang berusia 15-45 tahun yang diteliti, 0,8\% menderita asam urat tinggi (1,7\% pria dan $0,05 \%$ wanita di antara mereka sudah sampai pada tahap gout) (3).

Berdasarkan hasil RISKESDAS 2013 prevalensi penyakit sendi berada di urutan ketiga penyakit tidak menular setelah stroke $(57,9 \%)$ dan hipertensi $(36,8 \%)$, prevalensi penyakit sendi berdasarkan diagnosis meningkat seiring dengan bertambahnya umur, prevalensi penyakit sendi yaitu $24,7 \%$. (4).

Faktor yang dapat mempengaruhi penyakit gout arthritis yaitu kurangnya pengetahuan masyarakat mengenai nyeri pada sendi karena tidak semua keluhan dari nyeri sendi disebabkan oleh asam urat. Penyakit rematik banyak jenisnya, untuk memastikannya perlu pemeriksaan dilaboratorium. Pencegahan suatu penyakit akan lebih diperhatikan oleh seseorang terhadap obyek melalui indera yang dimilikinya (mata, hidung telinga dan sebagainya) pengetahuan menjadi salah satu yang sangat berpengaruh terhadap perilaku kesehatan (3).

Selain pengetahuan, faktor sosial ekonomi juga mempengaruhi terjadinya penyakit gout arthritis. Dari hasil sebuah studi tentang kondisi sosial ekonomi dan kesehatan lansia yang dilaksanakan Komnas lansia di 10 propinsi tahun 2010 diketahui penyakit yang terbanyak 
diderita lansia adalah penyakit sendi (52,3\%), hipertensi $(38,8 \%)$, anemia $(30,7 \%)$ dan katarak $(23 \%)$.

Berdasarkan data dari Puskesmas Lawanga tahun 2014 berjumlah 103 pasien lansia yang menderita gout arthritis dan pada tahun 2015 berjumlah 162 pasien lansia. Dari jumlah prevalensi diatas menunjukan adanya peningkatan pasien dari tahun ke tahun, sedangkan data dari puskesmas Lawanga dari bulan januari sampai bulan mei tahun 2016 didapatkan data sekitar 46 pasien gout arthritis. (5)

\section{METODE}

Penelitian ini menggunakan desain analitik hubungan antara pengetahuan, dukungan keluarga dan sosial ekonomi dengan penyakit gout arthritis pada lansia. Dengan pendekatan Cross Sectional (potong lintang). Populasi yaitu responden yang menderita penyakit gout arthritis di wilayah kerja Puskesmas Lawanga berjumlah 46 orang. Penentuan sampel dengan menggunakan total sampling. Penelitian ini dilakukan di Di Wilayah Kerja Puskesmas Lawanga. Data dianalisis dengan uji statistk Chi-Square dengan menggunakan program SPSS.

\section{HASIL}

Tabel 1

Distribusi Karakteristik Responden Berdasarkan Jenis Kelamin Penderita Penyakit Gout Arthritis

\begin{tabular}{lccc}
\hline Karakteristik & Kategori & Frekuensi (f) & Persen\% \\
\hline Jenis & Laki-laki & 21 & 45,7 \\
Kelamin & Perempuan & 25 & 54,3 \\
Total & & 46 & 100 \\
\hline
\end{tabular}

Berdasarkan tabel 1. diatas, menunjukkan bahwa dari 46 responden 25 orang $(54,3 \%)$ adalah responden yang berjenis kelamin perempuan, sedangkan 21 orang $(45,7 \%)$ adalah responden yang berjenis kelamin laki-laki. 
Tabel 2

Distribusi Karakteristik Responden Berdasarkan Pendidikan Penderita Penyakit Gout Arthritis

\begin{tabular}{llll}
\hline Karakteristik & Kategori & Jumlah & Persen\% \\
\hline Pendidikan & SD & 7 & 15,2 \\
& SMP & 13 & 28,3 \\
& SMA & 20 & 43,5 \\
& PT & 6 & 13,0 \\
\hline Total & 46 & & 100 \\
\hline
\end{tabular}

Berdasarkan tabel 2 menunjukkan bahwa dari 46 responden sebagian besar pendidikan SMA yaitu sebanyak 20 responden (43,5\%) kemudian pendidikan SMP yaitu sebanyak 13 responden $(28,3 \%)$ kemudian pendidikan SD yaitu sebanyak 7 responden $(15,2 \%)$ dan yang paling sedikit Perguruan Tinggi yaitu sebanyak 6 responden $(13,0 \%)$

Tabel 3

Distribusi Karakteristik Responden Berdasarkan Pekerjaan Penderita Penyakit Gout Arthritis

\begin{tabular}{llll}
\hline Karakteristik & Kategori & Jumlah & Persen\% \\
\hline Pekerjaan & PNS & 2 & 4,3 \\
& TNI/POLRI & 1 & 2,2 \\
& Wiraswasta & 12 & 26,1 \\
& Petani & 3 & 6,5 \\
& Pensiunan & 12 & 26,1 \\
& Lain-Lain & 16 & 34,8 \\
\hline Total & 46 & & 100
\end{tabular}

Berdasarkan tabel 3 menunjukkan bahwa dari 46 responden sebagian besar responden sudah tidak bekerja yaitu 16 responden (34,8\%) kemudian pensiunan sebanyak 12 responden $(26,1 \%)$ sama dengan wiraswasta sebanyak 12 responden $(26,1 \%)$ kemudian petani sebanyak 3 responden $(6,5 \%)$ kemudian PNS sebanyak 2 responden (4,3\%) dan paling sedikit TNI yaitu 1 responden $(2,2 \%)$.

Tabel 4

Distribusi Frekuensi Responden Berdasarkan Variabel Pengetahuan Pada Penderita Gout Arthritis

\begin{tabular}{llc}
\hline Pengetahuan & N & $\%$ \\
\hline Baik & 29 & 63,0 \\
Kurang & 17 & 37,0 \\
\hline Total & 46 & 100 \\
\hline
\end{tabular}

Berdasarkan tabel 4 menunjukan bahwa dari 46 responden yang memiliki pengetahuan baik sebanyak 29 responden $(63,0 \%)$ dan yang memiliki pengetahuan kurang sebanyak 17 responden $(37,0 \%)$. 
Tabel 5

Distribusi Frekuensi Responden Berdasarkan Variabel Sosial Ekonomi Pada Penderita Gout

Arthritis

\begin{tabular}{lcc}
\hline Sosial Ekonomi & N & $\%$ \\
\hline Rendah & 27 & 58,7 \\
Tinggi & 19 & 41,3 \\
\hline Total & 46 & 100 \\
\hline
\end{tabular}

Berdasarkan tabel 5 menunjukkan bahwa dari 46 responden yang memiliki sosial ekonomi rendah yaitu sebanyak 27 responden $(58,7 \%)$ dan yang memiliki sosial ekonomi tinggi yaitu sebanyak 19 responden $(41,3 \%)$.

Tabel 6

Distribusi Frekuensi Responden Berdasarkan Variabel Penyakit Gout Arthritis

\begin{tabular}{llc}
\hline Gout Arthritis & $\mathrm{N}$ & $\%$ \\
\hline Normal & 20 & 56,5 \\
Hiperuricemia & 26 & 43,5 \\
\hline Total & 46 & 100 \\
\hline
\end{tabular}

Berdasarkan tabel 6 menunjukan bahwa dari 46 responden yang Gout arthritis dalam keadaan Hiperuricemia sebanyak 26 responden $(43,5 \%)$ dan Gout arthritis dalam keadaan Normal sebanyak 20 responden $(56,5 \%)$.

Tabel 7

Gambaran Hubungan Pengetahuan Dengan Penyakit Gout Arthritis Pada Lansia Di Wilayah Kerja Puskesmas Lawanga Tahun 2016

\begin{tabular}{|c|c|c|c|c|c|c|c|}
\hline \multirow{3}{*}{ Pengetahuan } & \multicolumn{4}{|c|}{ Penyakit Gout Arthritis } & \multirow{2}{*}{\multicolumn{2}{|c|}{ Total }} & \multirow{3}{*}{ P-Value } \\
\hline & \multicolumn{2}{|c|}{ Hiperuricemia } & \multicolumn{2}{|c|}{ Normal } & & & \\
\hline & $\mathrm{F}$ & $\%$ & $\mathrm{~F}$ & $\%$ & $\mathrm{~F}$ & $\%$ & \\
\hline Baik & 13 & 28.3 & 16 & 34.8 & 29 & 63.0 & \\
\hline Kurang & 13 & 28.3 & 4 & 8.7 & 17 & 37.0 & 0.036 \\
\hline Jumlah & 26 & 56.5 & 20 & 43.5 & 46 & 100 & \\
\hline
\end{tabular}

Berdasarkan tabel 7 terdapat 13 responden $(28,3 \%)$ yang berpengetahuan baik dengan penyakit gout arthritis dalam keadaan hiperuricemia dan sebanyak 16 responden $(34,8 \%)$ yang berpengetahuan baik dengan penyakit gout arthritis dalam keadaan normal kemudian terdapat 13 responden $(28,3 \%)$ yang berpengetahuan kurang dengan penyakit gout arthritis dalam keadaan 
hiperuricemia dan sebanyak 4 responden $(8,7 \%)$ yang berpengetahuan kurang dengan penyakit gout arthritis dalam keadaan normal.

Berdasarkan uji Chi square diperoleh nilai $\mathrm{p}=0,036$, karena nilai $\mathrm{p}<0,05$ maka dapat disimpulkan Ha diterima dan Ho ditolak yaitu terdapat hubungan pengetahuan dengan penyakit gout arthritis pada lansia di wilayah kerja Puskesmas Lawanga Tahun 2016.

Tabel 8

Gambaran Hubungan sosial ekonomi dengan Penyakit Gout Arthritis pada Lansia di Wilayah Kerja Puskesmas Lawanga Tahun 2016

\begin{tabular}{llllllll}
\hline \multirow{2}{*}{$\begin{array}{c}\text { Sosial } \\
\text { Ekonomi }\end{array}$} & \multicolumn{4}{c}{ Penyakit Gout Arthritis } & \multirow{2}{*}{ Total } & P-Value \\
\cline { 2 - 6 } & \multicolumn{2}{c}{ Hiperuricemia } & & Normal & & & \\
\cline { 2 - 6 } & $\mathrm{F}$ & $\%$ & $\mathrm{~F}$ & $\%$ & $\mathrm{~F}$ & $\%$ \\
\hline Rendah & 12 & 26,1 & 15 & 32.6 & 27 & 58.7 \\
\hline Tinggi & 14 & 30.4 & 5 & 10.9 & 19 & 41.3 & \multirow{2}{*}{0.047} \\
\hline Jumlah & 26 & 56.5 & 20 & 43.5 & 46 & 100 & \\
\hline
\end{tabular}

Berdasarkan tabel 8 terdapat 12 responden $(26,1 \%)$ yang sosial ekonomi rendah dengan penyakit gout arthritis dalam keadaan hiperuricemia dan sebanyak 15 responden $(32,6 \%)$ yang sosial ekonomi rendah dengan penyakit gout arthritis dalam keadaan normal kemudian terdapat 14 responden $(30,4 \%)$ yang sosial ekonomi tinggi dengan penyakit gout arthritis dalam keadaan hiperuricemia dan sebanyak 5 responden $(10,9 \%)$ yang sosial ekonomi tinggi dengan penyakit gout arthritis dalam keadaan normal.

Berdasarkan uji Chi square diperoleh nilai $\mathrm{p}=0,047$, karena nilai $\mathrm{p}<0,05$ maka dapat disimpulkan Ha diterima dan Ho ditolak yaitu terdapat hubungan sosial ekonomi dengan enyakit gout arthritis pada Lansia di wilayah kerja Puskesmas Lawanga Tahun 2016.

\section{PEMBAHASAN}

\section{Hubungan Pengetahuan dengan Penyakit Gout Arthritis pada Lansia di Wilayah Kerja} Puskesmas Lawanga.

Pengetahuan merupakan perhatian individu yang dapat memberikan rasa ingin tahu pada suatu objek serta domain yang sangat penting untuk terbentuknya tindakan seseorang, dalam penelitian ini pengetahuan responden yang sudah baik membuat mereka membatasi makanan yang tinggi purin dan mengetahui gejala apa saja yang dapat ditimbulkan oleh gout arthritis 
misalnya nyeri pada sendi, sedangkan pada responden yang berpengetahuan kurang mereka belum mengetahui tentang makanan apa saja yang mempengaruhi gout arthritis, misalnya jeroan dan alkohol. Dalam hal ini menyebabkan perilaku responden tidak membatasi makanan yang mengandung purin, hal tersebut dipengaruhi oleh kurangnya informasi kepada responden.

Menurut Pipit, dkk (2010) ada beberapa faktor yang mempengaruhi pengetahuan yaitu pendidikan, informasi dan ekonomi, karena dari pengalaman dan penelitian ternyata perilaku yang didasari pengetahuan akan lebih langgeng daripada perilaku yang tidak didasari pengetahuan. Pengetahuan sangat erat kaitannya dengan beberapa faktor yang pertama adalah pendidikan. Pendidikan merupakan usaha untuk mengembangkan kepribadian dan kemampuan. Orang yang berpendidikan tinggi akan semakin luas pula pengetahuannya namun seseorang yang berpendidikan rendah tidak berarti mutlak berpengetahuan rendah pula, yang kedua adalah media massa atau informasi, informasi yang diperoleh baik dari pendidikan formal maupun nonformal dapat memberikan pengaruh jangka pendek sehingga menghasilkan perubahan dan peningkatan pengetahuan. (6)

Hasil penelitian ini juga sesuai dengan pendapat Notoadmodjo (2011) bahwa pengetahuan adalah merupakan hasil dari "tahu" dan ini terjadi setelah orang mengadakan penginderaan terhadap suatu objek tertentu. Penginderaan terhadap objek terjadi melalui panca indra manusia yakni penglihatan, pendengaran, penciuman, rasa dan raba dengan sendiri. Pada waktu pengindraan sampai menghasilkan pengetahuan tersebut sangat dipengaruhi oleh intensitas perhatian persepsi terhadap objek. Sebagian besar pengetahuan manusia diperoleh melalui mata dan telinga. (7)

Pengetahuan atau kognitif merupakan domain yang sangat penting untuk terbentuknya tindakan seseorang. Pengetahuan seseorang tentang suatu objek mengandung dua aspek yaitu aspek positif dan aspek negatif. Dari pengalaman dan penelitian ternyata perilaku yang didasari oleh pengetahuan akan lebih langgeng daripada perilaku yang tidak didasari oleh pengetahuan. Pengetahuan yang cukup di dalam domain kognitif mempunyai 6 tingkat yaitu : tahu, memahami, aplikasi, analisis, sintesis dan evaluasi ( 7)

Penelitian ini sejalan dengan penelitian yang dilakukan oleh Vamiluwati (2009) bahwa ada hubungan yang bermakna antara pengetahuan dengan penyakit gout arthritis dan Ashar (2008) bahwa pengetahuan lansia berpengaruh terhadap penyakit gout arthritis.(8) 


\section{Hubungan Sosial Ekonomi dengan Penyakit Gout Arthritis pada Lansia di wilayah kerja Puskesmas Lawanga Tahun 2016}

Sosial ekonomi adalah keadaan atau kemampuan lansia dalam memenuhi kebutuhannya untuk mencapai kemakmuran dan kesejahteraan, Status sosial ekonomi juga sangat dipengaruhi oleh tingkat pendapatan keluarga. Dalam penelitian ini rata-rata pendapatan paling banyak yaitu < Rp. 1.800.000.

Menurut Kartono (2008) sosial ekonomi adalah kedudukan seseorang atau keluarga di masyarakat berdasarkan pendapatan per bulan. Status ekonomi dapat dilihat dari pendapatan yang disesuaikan dengan harga barang pokok. (10)

Menurut Soekanto (2011) status sosial ekonomi merupakan posisi yang ditempati individu atau keluarga yang berkenaan dengan ukuran rata-rata yang umum berlaku tentang kepemilikan kultural, pendapatan efektif, pemilikan barang dan partisipasi dalam aktifitas kelompok dari komunitasnya, sehingga dapat disimpulkan bahwa status sosial ekonomi adalah tinggi rendahnya prestise yang dimiliki seseorang berdasarkan kedudukan yang dipegangnya dalam suatu masyarakat berdasarkan pada pekerjaan untuk memenuhi kebutuhannya atau keadaan yang atau kedudukan suatu keluarga masyarakat berdasarkan kepemilikan materi. Selain ditentukan oleh kepemilikan materi, status sosial ekonomi seseorang yang didasarkan pada beberapa unsur kepentingan manusia dalam kehidupannya, status dalam kehidupan masyarakat, yaitu status pekerjaan, status dalam sistem kekerabatan, status jabatan dan status agama yang dianut. (10)

Dengan memiliki status seseorang dapat berinteraksi dengan baik terhadap individu lain ( baik status yang sama maupun status yang berbeda), bahkan banyak pergaulan sehari-hari seseorang yang tidak mengenal seseorang secara individu, namun hanya mengenal status individu tersebut. Status sosial ekonomi sangat berkaitan dengan seseorang atau keluarga dalam masyarakat serta usaha untuk menciptakan barang dan jasa demi terpenuhinya kebutuhan baik jasmani maupun Rohani.

Penelitian ini didukung oleh Harniwita (2008) bahwa apabila penghasilan keluarga meningkat, penyediaan lauk pauk akan meningkat mutunya, sebaliknya penghasilan yang rendah menyebabkan daya beli yang rendah pula, sehingga tidak mampu membeli pangan dalam jumlah yang diperlukan. (11) 


\section{KESIMPULAN}

Berdasarkan hasil penelitian dan pembahasan penelitian faktor-faktor yang berhubungan dengan penyakit gout arthritis pada lansia di Wilayah Kerja Puskesmas Lawanga, maka dapat ditarik kesimpulan sebagai berikut faktor pengetahuan dan social ekonomi berhubungan dengan penyakit gout arthritis pada lansia di Wilayah Kerja Puskesmas Lawanga.

\section{DAFTAR PUSTAKA}

1. Junaidi, I. Rematik dan Asam Urat, PT Bhuana Ilmu Populer, Jakarta. 2013

2. Maas, M.L. Asuhan Keperawatan Geriatrik. Jakarta: Penerbit Buku Kedokteran. 2011

3. Hamidatu, Ulfiyah. Hubungan Antara Tingkat Pengetahuan Dengan Perilaku Wanita Menopause Dalam Upaya Pencegahan Penyakit Gout Di Kelurahan Pisangan, skripsi UIN syarif hudayatullah Jakarta. 2013

4. DEPKES. Riset Kesehatan Daerah. Jakarta: DEPKES RI; 2013.

5. Dinas Kesehatan Kabupaten Poso. Profil Dinas Kesehatan Kabupaten Poso tahun 2015.

6. Pipit, F. Hubungan Antara Pola Makan dengan Kadar Asam Urat Darah Pada Wanita Post Menopause Di Posyandu Lansia Di Wilayah Kerja Puskesmas dr Soetomo Surabaya, Journal Keperawatan. 2010

7. Notoatmodjo, 2011. Pendidikan dan Perilaku Kesehatan, Rineka Cipta : Jakarta

8. Valumiwati. Hubungan antara pengetahuan tentang gout dengan penerapan pola hidup sehat pada penderita gout didesa Puluhan, Jatinom, Kabupaten Klaten. Skripsi Universitas Klaten. 2009

9. Kartono. Perilaku Manusia. ISBN. Jakarta. 2008

10. Soekanto. Peranan Sosial Suatu Pengantar, edisi baru : Rajawali pers, Jakarta. 2011

11. Harniwita. Pengaruh Tingkat Pendapatan Terhadap Gizi Keluarga Di Desa Buluh Cina Kecamatan Siak Hulu Kabupaten Kampar, Vol. IX, No. 1. Jurnal penelitian, (online). 2008 